\title{
Local versus global effects on changes of fossil diversity: paleoenvironmental interpretation of Triassic faunas of the Balaton Highland (Hungary)
}

\author{
Attila Vörös \\ Research Group for Paleontology, Hungarian Academy of Sciences \\ Hungarian Natural History Museum, Budapest
}

\begin{abstract}
The formations of the Balaton Highland provide a high-resolution record of various fossil groups (ammonoids, bivalves, brachiopods) from the Early Triassic to the Carnian, with remarkable changes in taxonomic diversity. The local data differ considerably from the gradually increasing global diversity trends of the respective fossil groups. Ammonoids are rare in the Early Triassic; during the Anisian they reach a diversity maximum and remain rather diverse until the Carnian. This is connected to the considerable deepening of the sedimentary basin in the Middle Triassic. The benthic fossil groups show almost inverse local trends. In the Early Triassic, the proliferation of bivalves largely follows the transgressive pulses in the shallow marine setting; brachiopods are represented solely by Lingula specimens. Both the bivalve and the brachiopod diversity culminate in the middle Anisian what is interpreted in terms of extensional tectonic movements: the rocky escarpments of the disintegrated carbonate platforms provided favorable biotopes for sessile benthic organisms. The benthic diversities decreased significantly in the rest of Middle Triassic, which is due to the significant deepening of the local basin floor. The benthic groups reached maximum diversity in the Carnian. This is attributed partly to the filling up and shallowing of the local basin, partly to redeposition in the course of platform progradations, carrying rich fossil shell material from the neighboring shallow marine environments to the basin. Simultaneously, the sudden increase of the humidity ("Carnian pluvial event") created extensive river systems in the European continent; the increasing supply of organic matter was favorable for the benthos in the marine environments.
\end{abstract}

Key words: Triassic, diversity, ammonoids, bivalves, brachiopods, Balaton Highland, Hungary

Address: A. Vörös: H-1083 Budapest, Ludovika tér 2, Hungary, e-mail: voros@nhmus.hu Received: April 21, 2010; accepted: September 27, 2010 


\section{Introduction}

The Balaton Highland is among the most important reference areas of the Tethyan Triassic stratigraphy (see Tozer 1984). Although this hilly terrain lacks the spectacular exposures and the Triassic sequences are far from being well-exposed, scattered and transient outcrops have yielded plenty of fossils, systematically collected over the past 150 years. Many ammonoid and brachiopod species were portrayed in the important pioneering monograph by Böckh $(1872,1873)$; thereafter the ammonoids were profusely illustrated by Mojsisovics (1882). The greatest contribution to the knowledge of the Triassic faunas of the Balaton Highland was made by the ambitious international project entitled "Wissenschaftliche Erforschung des Balatonsees" (Scientific Investigation of Lake Balaton) directed by L. Lóczy Sr. at the turn to the twentieth century. The product was a series of papers and monographs which provided records of numerous fossil groups, including microfossils. Special emphasis was given to the ammonoids (Diener, 1899, 1900; Arthaber 1903; Frech 1903), bivalves (Bittner 1901; Frech 1904, 1907; Kittl 1912), gastropods (Kittl 1900), and brachiopods (Bittner 1900; Frech 1904, 1907). The original fossil material described in the above-listed works has been deposited and is accessible in the collections of the Geological Institute of Hungary (MÁFI). The items of this repository were comprehensively enumerated by Szabó (1972).

In the last decades, partly in connection with the detailed geologic mapping project by the Geological Institute of Hungary, excavations and voluminous collections have been made in many important stratigraphic sections in the Balaton Highland. The Lower Triassic faunas, in comparison to those of the Southern Alps, were documented in detail by Broglio Loriga et al. (1990). After publishing some preliminary results (Vörös 1987, 1993; Vörös and Pálfy 1989), the Anisian to Carnian ammonoid record was presented in a stratigraphic context (Vörös 1998). The results have been integrated into a comprehensive volume on the geologic mapping (Budai et al. 1999). One part of the results contributed to the resurgence of the "Anisian/Ladinian boundary problem" (Vörös et al. 1996, 2003) where the Felsőörs section was a formal candidate for the Ladinian GSSP. Recently, the Middle Triassic Pelsonian Substage was re-evaluated and redefined (Vörös 2003a) and the fossil flora and fauna of the substage were documented in detailed systematic descriptions by Piros (2003, dasycladaceans), Vörös (2003b, ammonoids), Szente and Vörös (2003, bivalves), Pálfy (2003, brachiopods) and Kovács (2003, conodonts).

In summary, from the Balaton Highland we have a rather well-documented record of diverse fossil groups from the Early Triassic to the Carnian. Younger Triassic formations, e.g. the Carnian-Norian Main Dolomite (Fôdolomit Formation) and the Norian-Rhaetian Dachstein Limestone locally abound in megalodontids, and the Rhaetian Kössen Formation also yielded a rich bivalve fauna. Since these occurrences lie mostly in the Bakony Mountains, outside the Balaton Highland, they are beyond the scope of the present paper. 
A review of the Early Triassic to Carnian fossil documentation of the Balaton Highland reveals that three important fossil groups (ammonoids, bivalves and brachiopods) provide a more or less continuous record, with occurrences in almost all stages. It is also remarkable that their abundance and diversity (species richness) generally increases in time and the peak values are connected to specific stratigraphic levels. The general increase of diversity is consistent with the global change of the biosphere: the Triassic was a time of recovery after the end-Permian biotic catastrophe, when most fossil groups progressively diversified. On the other hand, the discrete episodes with diversity maxima (and minima) call upon local or regional paleoenvironmental causes, which override the global trends.

\section{Data of fossil occurrences in stratigraphic units}

The sources of data on ammonoid, bivalve and brachiopod diversity (species richness) of particular Triassic stratigraphic levels in the Balaton Highland, outlined in the introduction, are shown in Table 1, and will be detailed below. The Triassic (Induan to Carnian) formations of the Balaton Highland and the diversity values of ammonoids, bivalves and brachiopods in particular, in the selected stratigraphic levels, are shown in Fig. 1. The short descriptions of the formations are based mainly on the works by Budai and Haas (1997), Haas and Budai (1999, 2004).

1. Arács Formation (Induan). The 120 m-thick, mostly marine marl of this formation contains subordinate dolomitic and limestone interlayers and passes laterally (westward) into the supratidal Köveskál Dolomite. The locally abundant fossils ( 8 bivalve and 2 brachiopod taxa) of the Arács Marl were listed and figured by Broglio Loriga et al. (1990). Remarkably, the brachiopods are represented by two species of Lingula.

2. Zánka Sandstone Member (Hidegkút Formation, Lower Olenekian). The lower, 50 m-thick siliciclastic member of the Hidegkút Formation was previously called "Hidegkút Sandstone Member" and was attributed to the Upper Induan by Broglio Loriga et al. (1990). Recently, Budai and Haas (1997), Haas and Budai $(1999,2004)$ used the name Zánka Sandstone and assigned this member to the Lower Olenekian. This shallow marine, thinly laminated sandstone with limestone interlayers yielded only bivalves: 11 taxa were listed by Broglio Loriga et al. (1990). The upper member of the Hidegkút Formation, the mostly supratidal Hidegkút Dolomite, did not yield any fossils.

3. Csopak Formation (Upper Olenekian). This 200 m-thick, marl-dominated succession is the first formation of the Balaton Highland to have been deposited in a fully marine environment and reflects pelagic influence. Its fauna consists of 2 ammonoid, 12 bivalve and 1 brachiopod taxa, as demonstrated by Broglio Loriga et al. (1990). The single brachiopod taxon is a Lingula species. According to Budai and Haas (1997) the maximum flooding can be recognized in the middle 
Table 1

Selected stratigraphic levels (Triassic, Balaton Highland) and the species numbers and data sources of the respective faunas

\begin{tabular}{|c|c|c|c|c|}
\hline Ages/Formations & $\begin{array}{l}\text { Ammonoidea } \\
\text { species }\end{array}$ & $\begin{array}{l}\text { Bivalvia } \\
\text { species }\end{array}$ & $\begin{array}{l}\text { Brachiopoda } \\
\text { species }\end{array}$ & Sources \\
\hline $\begin{array}{l}\text { 1. Induan } \\
\text { Arács Formation }\end{array}$ & - & 8 & 2 & $\begin{array}{c}\text { Broglio Loriga et al. } \\
\qquad(1990)\end{array}$ \\
\hline $\begin{array}{l}\text { 2. Early Olenekian } \\
\text { Hidegkút Formation } \\
\text { (Zánka Member) }\end{array}$ & - & 11 & - & $\begin{array}{c}\text { Broglio Loriga et al. } \\
\qquad(1990)\end{array}$ \\
\hline $\begin{array}{l}\text { 3. Late Olenekian } \\
\text { Csopak Formation }\end{array}$ & 2 & 13 & 1 & $\begin{array}{c}\text { Broglio Loriga et al. } \\
(1990)\end{array}$ \\
\hline $\begin{array}{l}\text { 4. Early Anisian } \\
\text { Iszkahegy Formation }\end{array}$ & - & 2 & - & $\begin{array}{c}\text { Broglio Loriga et al. } \\
(1990)\end{array}$ \\
\hline $\begin{array}{l}\text { 5. Middle Anisian } \\
\text { (Balatonicus Zone) } \\
\text { Felsöörs Formation (lower part) }\end{array}$ & 29 & 35 & 34 & $\begin{array}{l}\text { Vörös (2003b), Pálfy } \\
\text { (1988, 2003) Szente } \\
\text { and Vörös (2003) }\end{array}$ \\
\hline $\begin{array}{l}\text { 6. Late Anisian } \\
\text { (Trinodosus Zone) } \\
\text { Felsöörs Formation (upper } \\
\text { part) }\end{array}$ & 24 & 8 & 18 & $\begin{array}{l}\text { Vörös and Pálfy } \\
\quad(1989) \\
\text { Vörös (1998) + } \\
\text { unpublished }\end{array}$ \\
\hline $\begin{array}{l}\text { 7. Late Anisian } \\
\text { (Reitzi Zone) } \\
\text { Vászoly Formation }\end{array}$ & 56 & 7 & 14 & $\begin{array}{c}\text { Vörös and Pálfy } \\
(1989) \\
\text { Vörös (1998) + } \\
\text { unpublished }\end{array}$ \\
\hline $\begin{array}{l}\text { 8. Early Ladinian } \\
\text { Buchenstein Formation } \\
\text { (lower part) }\end{array}$ & 9 & 4 & 3 & $\begin{array}{c}\text { Szabó (1972), Vörös } \\
(1998)\end{array}$ \\
\hline $\begin{array}{l}\text { 9. Late Ladinian } \\
\text { Buchenstein Formation } \\
\text { (upper part) }\end{array}$ & 31 & 17 & 8 & $\begin{array}{c}\text { Szabó (1972), Vörös } \\
\text { (1998) }\end{array}$ \\
\hline $\begin{array}{l}\text { 10. Carnian } \\
\text { Veszprém Formation + } \\
\text { Sándorhegy Formation }\end{array}$ & 30 & 142 & 81 & Szabó (1972) \\
\hline
\end{tabular}

part of the formation, coinciding with the occurrence of the ammonoids (Tirolites, Dalmatites).

4. Iszkahegy Formation (Lower Anisian). The lowermost Anisian, lagoonalperitidal Aszófó Dolomite $(200 \mathrm{~m})$, devoid of megafossils, is followed by the bioturbated, gray limestone of the Iszkahegy Formation. This 250 to $300 \mathrm{~m}$-thick succession was deposited in a restricted, partly anoxic basin on a carbonate ramp. The fauna of this shallow marine basin was very poor: Broglio Loriga et al. (1990) listed only two species of bivalves; ammonoids and brachiopods were not reported.

5. Felsőörs Formation, lower part (Middle Anisian, Balatonicus Zone). The carbonate ramp of the Lower to Middle Anisian, lagoonal Megyehegy Dolomite was affected by intensive extensional tectonics in the Middle Anisian, and a submarine topography of fault-bounded basins and horsts developed (Budai and 
Paleoenvironmental interpretation of Triassic faunas of the Balaton Highland (Hungary) 347

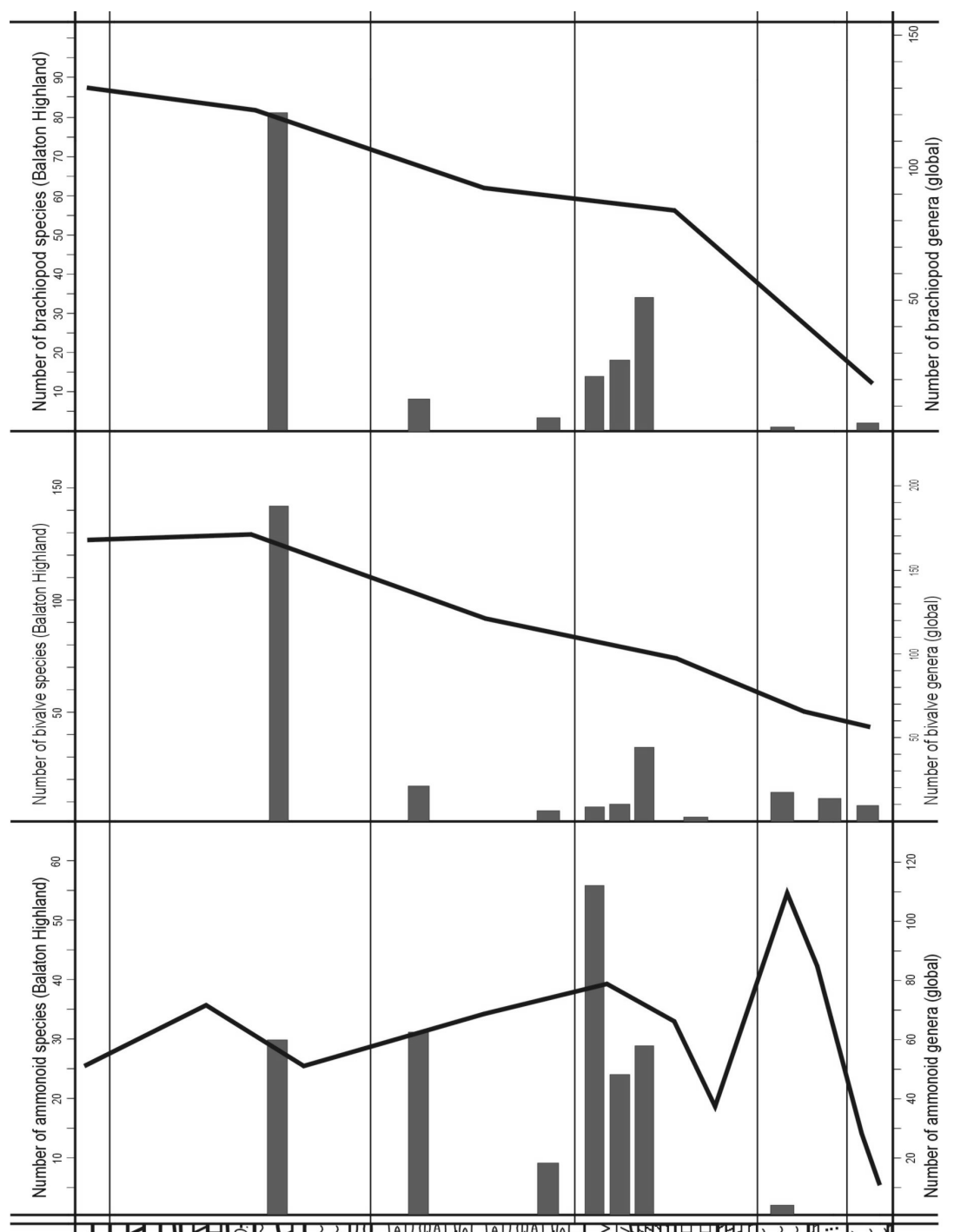

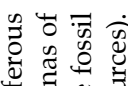

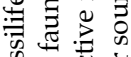

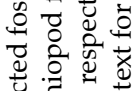

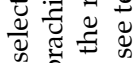

岁总苛

:

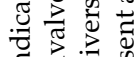

a

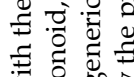

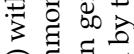

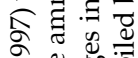

S.

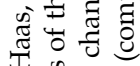

要

등 응

함

品.

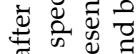

है के क्ष

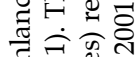

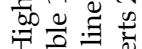

西: $:$

훙

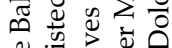

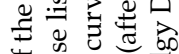

t)

过

ฮี ซี

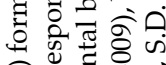

द्व

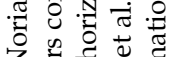

范实完

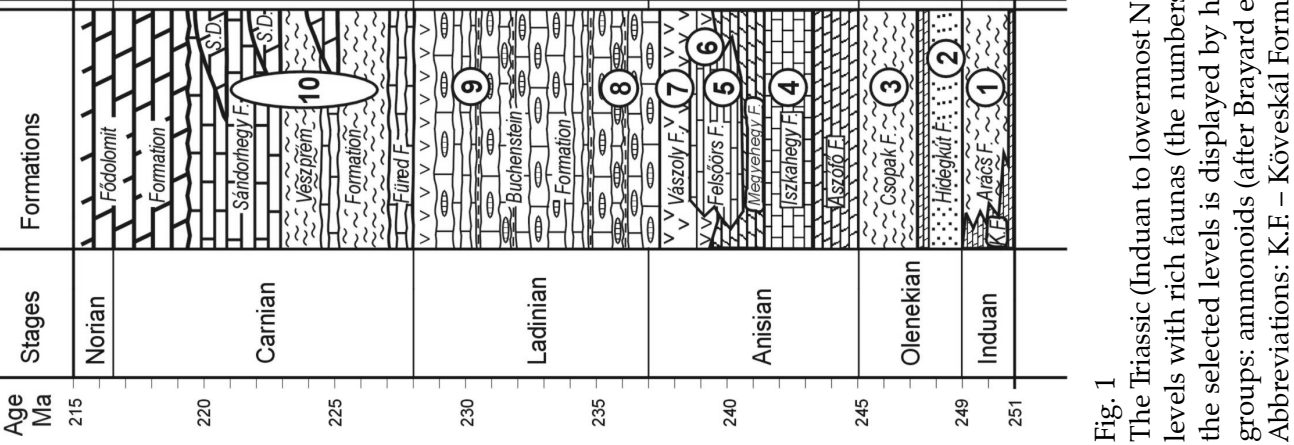

Central European Geology 52, 2009 
Vörös 1992; Haas and Budai 1995). In the basins, well-bedded, partly bituminous or cherty, fossiliferous limestone layers with clayey interlayers (Felsőörs Formation) were deposited. Along the submarine fault scarps the "Recoaro-type" crinoidal-brachiopodal limestone of the Horoghegy Member, especially rich in benthic fossils (Vörös and Pálfy 2002), has accumulated. The 20 to $80 \mathrm{~m}$-thick Pelsonian part of the formation (Balatonicus Zone) yielded 29 taxa of ammonoids (Vörös 2003b), 35 taxa of bivalves (Szente and Vörös 2003) and 34 taxa of brachiopods (Pálfy 1988, 2003).

6. Felsőörs Formation, upper part (Upper Anisian, Trinodosus Zone). The upper few tens of meters-thick part of this formation consist of gray, wellbedded, partly siliceous limestone with some tuffitic clay interlayers near the top. In consequence of its diachronous lower boundary, in some sections the deposition of the Vászoly Formation begins in the Trinodosus Zone; therefore these data were also included into this unit. The ammonoid fauna is very diverse (24 taxa: Vörös 1998). The bivalves are subordinate; 8 taxa, mostly at the genus level, have been identified by the present author. These data are in unpublished interim reports; therefore the taxa are listed here.

$\begin{array}{ll}\text { Palaeonucula sp. } & \text { Filopecten ? rosaliae } \\ \text { Daonella } \mathrm{sp} . & \text { Pteria } \mathrm{sp} . \\ \text { Posidonia sp. } & \text { Plagiostoma } \mathrm{sp} . \\ \text { Entolium sp. } & \text { Mysidioptera sp. }\end{array}$

The brachiopods are more diverse; the 18 taxa were identified partly by J. Pálfy (Vörös and Pálfy 1989), partly by the present author. The latter results are in unpublished interim reports; therefore the complete list is shown here.

$\begin{array}{ll}\text { Lingula sp. } & \text { Schwagerispira speciosa } \\ \text { Discinisca sp. } & \text { Mentzelia mentzeli } \\ \text { Norella refractifrons } & \text { Mentzelia aff. ampla } \\ \text { Holcorhynchella delicatula } & \text { Koeveskallina koeveskalyensis } \\ \text { Trigonirhynchella aff. delecta } & \text { Koeveskallina? pannonica } \\ \text { Piarorhynchella trinodosi } & \text { Angustothyris angustaeformis } \\ \text { Volirhynchia vivida } & \text { Angustothyris aff. suspecta } \\ \text { Volirhynchia productifrons } & \text { Pexidella sturi } \\ \text { Schwagerispira schwageri } & \text { Coenothyris aff. vulgaris }\end{array}$

7. Vászoly Formation (Upper Anisian, Reitzi Zone). With the onset of the pervasive volcanism, in the Reitzi Zone volcaniclastics became predominant over carbonates. In this, 2 to $20 \mathrm{~m}$-thick part of the Vászoly Formation the siliceous, cherty and nodular limestone forms $5-20 \mathrm{~cm}$-thick interlayers within the massive, greenish-gray to yellow tuffaceous strata. The limestone beds yielded plenty of ammonoids (56 species: Vörös 1998), which is the most diverse ammonoid fauna of the Balaton Highland. The bivalves are subordinate; 7 taxa 
have been identified by the present author, mostly at the genus level. These data are in unpublished interim reports; therefore the taxa are listed here.
Palaeonucula sp.
Mysidioptera sp.
Parallelodon cf. elongata
Myophoriopis sp.
Daonella sp.
Schafhaeutlia sp.

Posidonia sp.

The brachiopod fauna is moderately diverse; the 14 taxa were identified partly by J. Pálfy (Vörös and Pálfy 1989), partly by the present author. The latter results are in unpublished interim reports; therefore the complete list is given here.
Discinisca sp.
Mentzelia mentzeli
Norella refractifrons
Norella aff. rosaliae
Mentzelia mentzeli baconica
Trigonirhynchella aff. delecta
Mentzelia aff. ampla
Piarorhynchella trinodosi
Koeveskallina? pannonica
Volirhynchia vivida
Tetractinella trigonella
Schwagerispira speciosa
Pexidella sturi
Angustothyris aff. suspecta

8. Buchenstein Formation, lower part (Lower Ladinian, Fassanian). In the deep pelagic basin prevailing in the Balaton Highland in Ladinian times, red or gray cherty limestone was deposited in less than $80 \mathrm{~m}$ total thickness. The 10 to $30 \mathrm{~cm}$ thick beds of this Buchenstein Formation regularly contain thinner, clayey interlayers of volcanic origin. The diversity of ammonoids is considerably lower than in the underlying Vászoly Formation: 9 species were listed by Vörös (1998), though this scarcity may partly be due to preservational and collecting bias. The benthos was of extremely low diversity: the bivalves are represented exclusively by the genus Daonella (4 species: Szabó 1972); 3 brachiopod species were listed by Szabó (1972).

9. Buchenstein Formation, upper part (Upper Ladinian, Longobardian). The accumulation of the predominantly red, cherty limestone continued, but locally more fossiliferous, pure limestone was deposited. A major pulse of volcanism is marked by local appearance of massive tuffite layers. The pure, usually dark-red limestone yielded a very diverse ammonoid fauna (31 species: Vörös 1998). The shelly benthos shows also increasing diversity. Szabó (1972) listed 17 bivalve taxa (still predominated by the species of Daonella), and 8 brachiopod species.

10. Veszprém Formation, Sándorhegy Formation and Sédvölgy Members (Lower Carnian, Julian). The pelagic limestone succession of the Balaton Highland basin was terminated by the 10 to $60 \mathrm{~m}$-thick Füred Limestone. Then, within the Julian, the lithology changed significantly and thick (200 to $600 \mathrm{~m}$ ) marl was accumulated in the basin. The regional facies pattern became intricate: carbonate bodies, redeposited from a carbonate platform located to the east 
(Sédvölgy Dolomite), created massive tongues (partly called Buhimvölgy Breccia) within the marl series. A time equivalent of one of these progradational tongues is called Nosztor Member; this pelagic limestone of $20 \mathrm{~m}$ thickness divides the Veszprém Formation into a lower (Mencshely Member) and an upper (Csicsó Member) part. With the filling up of the basin, the prograding platform gradually occupied the region and the partly hypersaline, partly normal marine, fossiliferous limestone of the Sándorhegy Formation became dominant. Finally, in the late Carnian, the uniform, peritidal beds of the "Main Dolomite" (Fôdolomit Formation) started to be prevalent in the area and continued to be so up through most of the Late Triassic.

The above-described thick and lithologically complex series between the Füred Limestone and the Fődolomit Formation obviously represents various and very different paleoenvironments. Accordingly, its fossil fauna is extremely diverse: Szabó (1972) listed 30 ammonoid, 142 bivalve and 81 brachiopod taxa from the various members of the Veszprém Formation and the Sándorhegy Formation. This excessive richness of the bulk fauna is apparently due partly to paleoecological lumping because the fauna comprises fossils derived from various environments. The faunal lists of Szabó (1972) are based on the fossil material collected more than hundred years ago and deposited in the collections of the Geological Institute of Hungary (MÁFI). Most of the exposures of those times no longer exist, and the precise identification of the localities of the old fossil material was not yet possible. Moreover, neither taxonomic, nor nomenclatorial revisions of the listed taxa have been attempted. Thus it was not yet possible to undertake a revision of the Carnian fauna and, although the numbers of taxa given by Szabó (1972) are probably greatly exaggerated, they are used in the present paper without changes.

\section{Discussion}

Global versus local trends of fossil diversity

As a first step, the changes in diversity of ammonoids, bivalves and brachiopods recorded in the Balaton Highland were compared to global trends in diversity changes of the three fossil groups (Fig. 1). The species richness data given in Table 1 were used for measuring the local diversity. The global changes of diversity were plotted in terms of generic richness of the respective fossil groups. These data were taken from Brayard et al. (2009) for the ammonoids and from McRoberts (2001) for the bivalves; the brachiopod data were compiled by the present author, on the basis of recently revised volumes of the "Treatise on Invertebrate Paleontology", i.e. Savage et al. (2002), Alvarez and Rong (2002), Carter and Johnson (2006) and Lee et al. (2006). In most cases the local trends significantly deviate from the global ones.

The ammonoid trends, global and local, are more or less comparable in the Middle Triassic to Carnian period. Only the great Early Triassic global maximum 
has left no trace in the Balaton Highland record, which is obviously due to local factors. The pelagic (nektonic) ammonoids were not able to enter the very shallow seas of the area, far from the oceans.

For the bivalves, the global diversity gradually and almost constantly increases through the Triassic. The local diversity values are rather low but seem to follow more or less the global trend from the Early Triassic until the middle Anisian. Afterward the local diversity of bivalves decreases abruptly, but reaches a new peak in the Carnian. The explanation for this Middle Triassic negative anomaly lies in local paleogeographic circumstances discussed below.

On the global scale the brachiopod generic richness, after an abrupt rise in the Early Triassic, increases gradually toward the end of the period. The local record is extremely poor in the Early Triassic. Only the rare occurrence of the genus Lingula is remarkable. This genus is regarded as an emblematic "disaster form" by Schubert and Bottjer (1995); its appearance shortly after the end-Permian catastrophe fits with the global model of biotic changes following a mass extinction. The middle Anisian peak in the local diversity of brachiopods is followed by a sharp decrease in the rest of the Middle Triassic. This phenomenon and the massive Carnian peak call for local factors in their interpretation.

In summary, the local diversity data recorded in the Balaton Highland, and their changes throughout the Triassic, differ considerably from the global diversity trends of the respective fossil groups.

\section{Local factors governing the faunal changes}

It is not surprising to find the cause of the local faunal changes in local paleoenvironmental factors. Yet the different trends in the diversities of the different (nektonic, benthonic) fossil groups of the Triassic of the Balaton Highland and their evaluation may provide valuable new insights.

One of the most obvious long-term paleogeographic changes in the Triassic history of the Balaton Highland is the deepening of the sedimentary basin in the Middle Triassic and the shallowing in the Carnian (Haas 1994; Haas et al. 1995). After the slow Early Triassic transgression water depth reached a depth in excess of $500 \mathrm{~m}$ in the late Anisian basins (Vörös 1996) and might have approached 1,000 $m$ in the Ladinian (Budai and Haas 1997). The latter work is the source of the depth curve in Fig. 2, which shows the percentage of the ammonoid species against the proportion of the benthic species (i.e. the sum of the bivalve and brachiopod species) in the selected levels. The proportion of the ammonoids shows a distinct correlation with the depth curve. Remarkably, the first appearance of the ammonoids matches well with the late Olenekian transient deepening (level 3), when water depth exceeded $200 \mathrm{~m}$ for the first time in the Triassic. It seems that this transgression, resulting in the critical water depth, established the condition for the immigration of ammonoids from the Tethys Ocean into the shallow shelf basin of the Balaton Highland. 


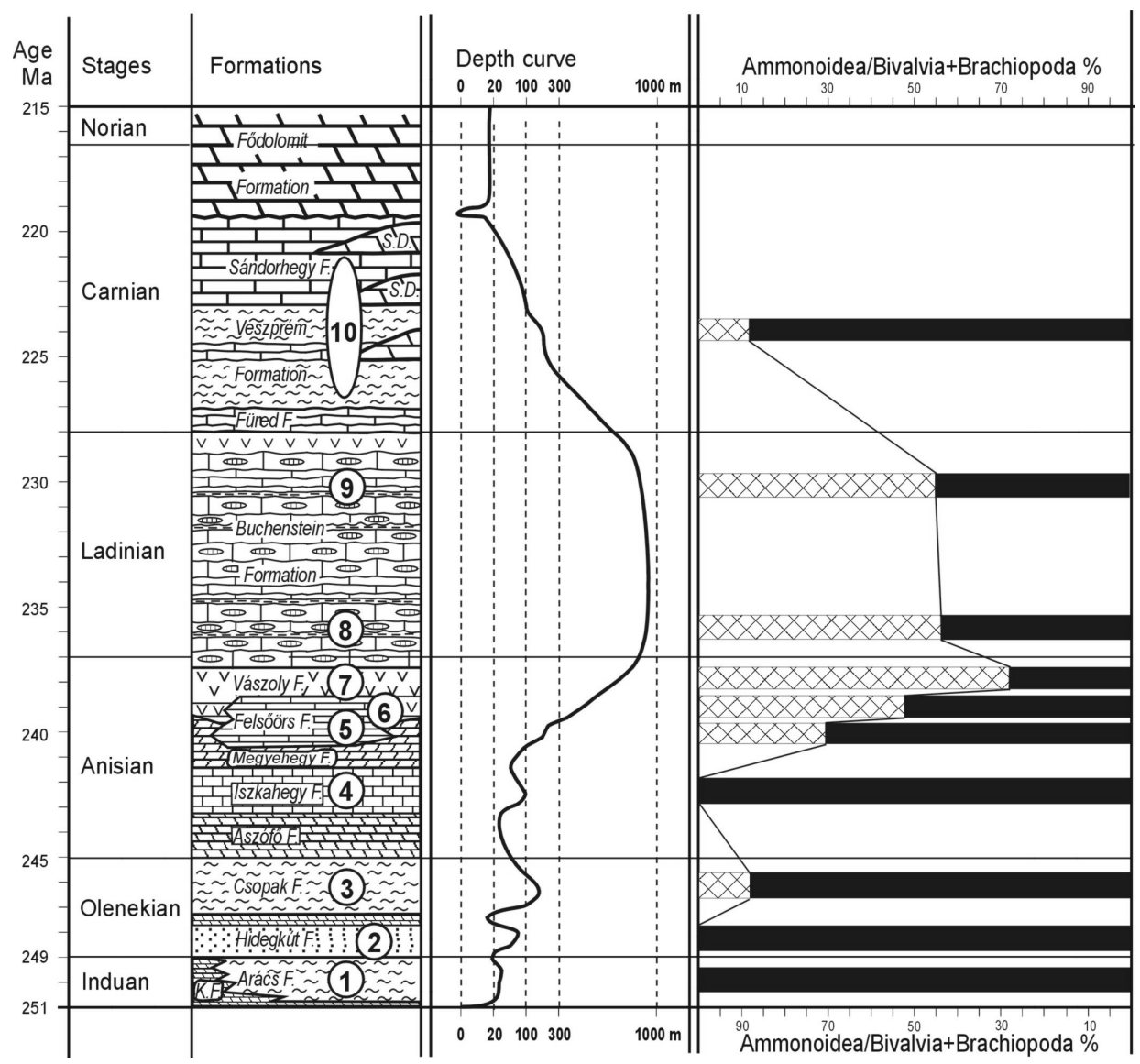

Fig. 2

The Triassic formations of the Balaton Highland with the indication of selected fossiliferous levels and the depth curve of the basinal areas (after Budai and Haas 1997), also showing the percentages of the ammonoid species (cross-hatched) against the proportion of the sum of the bivalve and brachiopod species (black) in the selected levels. Other sources and abbreviations as in Fig. 1

Figure 2 also shows the inverse relationship between the water depth and the proportion of the benthic species (bivalves and brachiopods). The obvious, generalized explanation is that the several hundred meters-deep sea-floor was unfavorable for the benthic organisms. In order to reveal some more specific causes of the diversity peaks of the benthic groups we must consider further local and regional environmental factors.

Some of the major local and regional events and environmental factors (except the depth of the sea water) of the Balaton Highland are illustrated in Fig. 3, and their correlation with the changes in lithology and the diversity peaks of the benthic fossil groups are also shown. 
Paleoenvironmental interpretation of Triassic faunas of the Balaton Highland (Hungary) 353

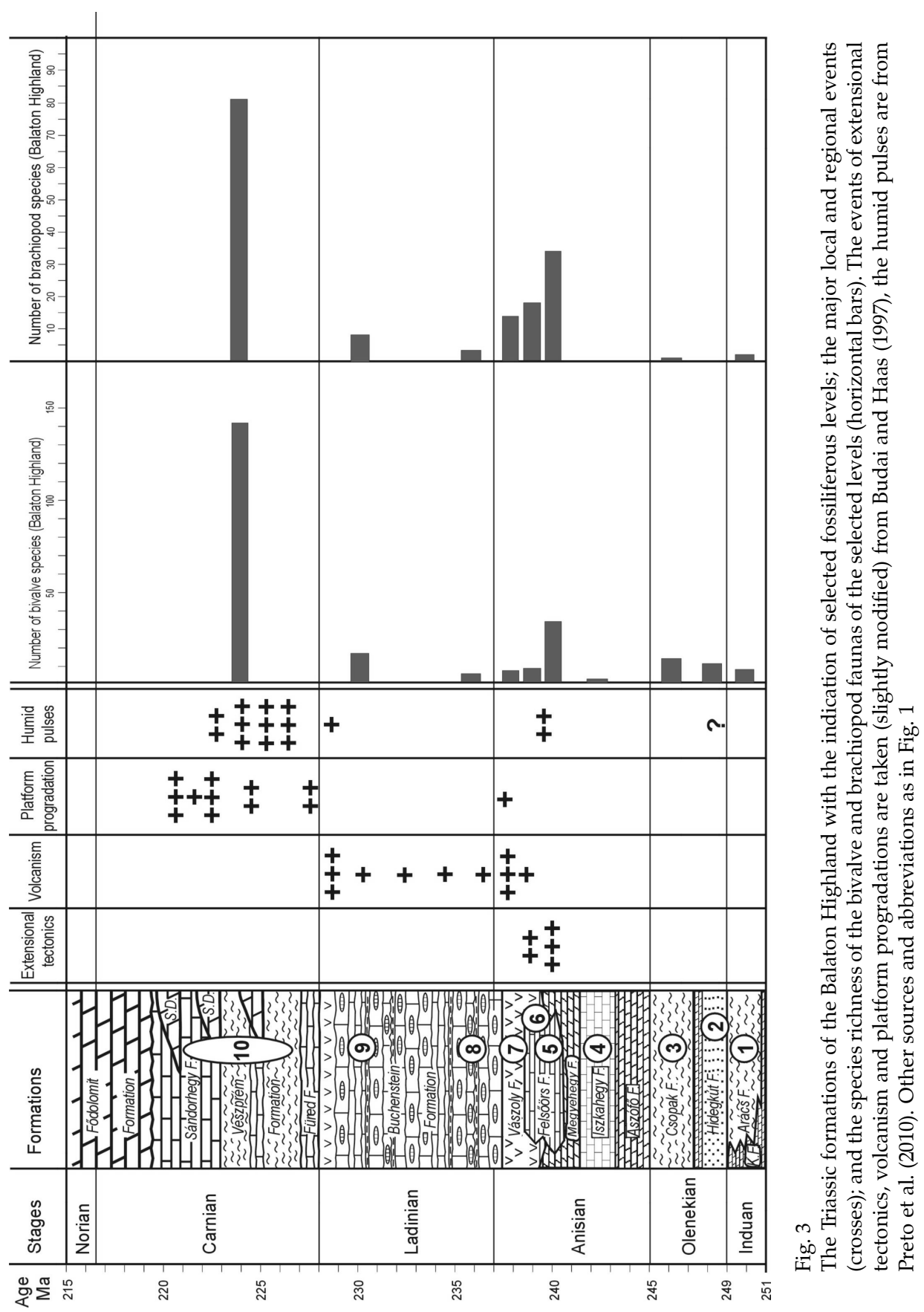


In the Early Triassic, the benthos was represented mainly by the bivalves. The diversity peaks of these mostly cosmopolitan taxa are connected to the transgressive episodes in the shallow marine area of the Balaton Highland, as already pointed out by Broglio Loriga et al. (1990).

The Middle Anisian extensional tectonic movements seem to provide the first forceful effect on the benthic diversities. According to the paleogeographic models of Budai and Vörös (1992) and Vörös et al. (1997) the rocky escarpments and slopes of the disintegrated carbonate platforms could have served as favorable biotope for brachiopods, bivalves and other sessile benthic organisms. After death, the shells and skeletons were carried downslope to the neighboring basin and formed mass accumulations ("Recoaro-type" limestone) in the Felsőörs Formation. The regional humid climatic pulse, documented by Preto et al. (2010), might have resulted in increased fluvial influx, carrying extensive amounts of organic matter from the land areas. This input of food supply might have enhanced the proliferation of the benthic communities.

Later, in the course of the Middle Triassic, the diversity values of the benthic communities slowly but significantly decreased. This is obviously connected with the gradual and considerable deepening of the local basin floor. The rocky surfaces, i.e. the hard substrate, diminished and the basin reached a starved state, with very limited nutrient supply. The muddy bottom provided only limited possibilities for the burrowing organisms, whereas the sessile benthos largely disappeared. The Ladinian bivalve communities are dominated by "flat clams" or "paper pectens" (Daonella s. 1.) which were commonly believed to belong to the pseudoplankton, i.e. living attached to floating objects (algae, etc.). Alternatively, Schatz (2005) argued for a benthic, pleurothetic mode of life ("snow-shoe strategy"), but in any case, the linkage of the daonellids to the soft sediments is obvious. The more or less continuous volcanism during the late Anisian and Ladinian had no detectable influence on the benthic diversity.

The massive peak of benthic diversity in the Carnian requires a complex explanation. As was emphasized in the previous chapter these data represent a "bulk fauna", once collected from diverse lithologies of several different formations of early and middle Carnian age. The presently used data base (Szabó 1972) contains faunal lists without modern revision. Although these two factors likely greatly exaggerate the taxonomic richness of the Carnian fauna, it may be confidently stated that it represents a true maximum in the local benthic diversity.

This real and significant diversity increase can be attributed to changes in three independent environmental factors. These are related to three specific features of the Carnian basin evolution of the Balaton Highland (Haas 1994; Budai and Haas 1997). (1) The rapid accumulation of several hundred meters-thick marly strata (Veszprém Marl) led to the shallowing of the basin, providing more favorable habitats for benthic life. (2) The increasing degree of platform progradation supplied large volumes of redeposited, platform-derived carbonates (Sédvölgy Dolomite tongues, Buhimvölgy Breccia) culminating in the widespread Sándor- 
hegy Formation. The redeposited carbonates carried rich fossil assemblages from the neighboring shallow marine settings into the basin. This paleoecological mixing of faunas from various environments greatly increased the bulk diversity. (3) Both above factors might have been intensified by the sudden increase of humidity in the wider region. Although the paleobotanical evidence of this "Carnian pluvial event" in Europe was challenged by Visscher et al. (1994), recent studies support the idea of the "wet Carnian", also called the "Reingraben event" or "megamonsoon" (Bourquin and Guillocheau 1996; Rigo et al. 2007; Hornung et al. 2007; Preto et al. 2010). This large-scale humid pulse created extensive river systems in the European continent which greatly increased the supply of organic matter and enhanced benthic life in the surrounding marine basins, just as in the Balaton Highland.

\section{Conclusions}

The global diversity of the ammonoids, bivalves and brachiopods show a gradual increase throughout the Triassic, whereas the local diversity data recorded in the Balaton Highland, differ considerably from the global trend. These deviations are interpreted in terms of local paleoenvironmental changes.

The deepening of the sedimentary basin in the Middle Triassic and the shallowing in the Carnian is clearly expressed in the high percentage of the ammonoid species compared to the benthic species. It seems that a critical water depth of $200 \mathrm{~m}$ was necessary for immigration of ammonoids from the Tethys Ocean to the shallow shelf basin of the Balaton Highland.

The middle Anisian extensional tectonic movements increased the benthic diversities: the rocky escarpments of the disintegrated carbonate platforms provided biotopes for brachiopods, bivalves and other sessile benthic organisms. This is expressed in the middle and late Anisian diversity peaks.

The significant decrease in benthic diversity higher up in the Middle Triassic is obviously connected to the gradual and considerable deepening of the local basin floor

The massive Carnian peak of benthic diversity can be attributed to three independent environmental factors. (1) The filling up and shallowing of the local basin was favorable for benthic life. (2) At times of platform progradation, the redeposited carbonates carried rich fossil assemblages from the neighboring shallow marine settings into the basin. (3) The sudden increase of humidity ("Carnian pluvial event") created extensive river systems in the European continent, greatly increasing the supply of organic matter and enhancing the proliferation of benthos in the marine environments.

\section{Acknowledgements}

The author is indebted to J. Pálfy and I. Szente for their contributions to the paleontological data and to T. Budai, G. Csillag and I. Szabó for field trips and for their help in the interpretation of the local geology. The useful reviewer's 
comments and corrections of T. Budai and J. Pálfy are gratefully acknowledged. The study was supported by the grants T 43325 and K 81298 of the Hungarian Scientific Research Fund (OTKA).

\section{References}

Alvarez, F., Rong Jia-yu, 2002: Athyridida. - In: Kaesler, R.L. (Ed.): Treatise on Invertebrate Paleontology. Part H, Brachiopoda (Revised), Volume 4, Rhynchonelliformea (part). Geological Society of America and University of Kansas, Boulder, Colorado and Lawrence, Kansas, pp. 1475-1614.

Arthaber, G. 1903: Neue Funde in der Werfener Schichten und im Muschelkalk des südl. Bakony und Revision der Cephalopodenfauna des Muschelkalkes. (Separatabdruck) - In: Resultate der wissenschaftlichen Erforschung des Balatonsees, 1 (1), Anhang: Palaeontologie der Umgebung des Balatonsees, 3/3, pp. 1-26.

Bittner, A. 1900: Brachiopoden aus der Trias des Bakonyerwaldes. - In: Resultate der wissenschaftlichen Erforschung des Balatonsees, 1, Anhang: Palaeontologie der Umgebung des Balatonsees, 2/1, pp. 1-59.

Bittner, A. 1901: Lamellibranchiaten aus der Trias des Bakonyerwaldes. - In: Resultate der wissenschaftlichen Erforschung des Balatonsees, 1 (1), Anhang: Palaeontologie der Umgebung des Balatonsees, 2/3, pp. 1-107.

Bourquin, S., F. Guillocheau 1996: Keuper stratigraphic cycles in the Paris Basin and comparison with cycles in other Peritethyan basins (German Basin and Bresse-Jura Basin). - Sedimentary Geology, 105, pp. 159-182.

Böckh, J. 1872: A Bakony déli részének földtani viszonyai. I. (The geological features of the southern part of the Bakony. I) - A Magyar Királyi Földtani Intézet Évkönyve, 2/2, pp. 31-166. (In Hungarian.)

Böckh, J. 1873: Die geologischen Verhältnisse des südlichen Theiles des Bakony, I. - Mittheilungen aus dem Jahrbuche der königlichen ungarischen geologischen Anstalt, 2/2, pp. 27-182.

Brayard, A., G. Escarguel, H. Bucher, C. Monnet, T. Brühwiler, N. Goudemand, T. Galfetti, J. Guex 2009: Good genes and good luck: ammonoid diversity and the end-Permian mass extinction. Science, 325, pp. 1118-1121 (+ supporting online material).

Broglio Loriga, C., F. Góczán, J. Haas, K. Lenner, C. Neri, A. Oravecz-Scheffer, R. Posenato, I. Szabó, Á. Tóth-Makk 1990: The Lower Triassic sequences of the Dolomites (Italy) and Transdanubian Mid-Mountains (Hungary) and their correlation. - Memorie di Scienze Geologiche, 42, pp. 41-103.

Budai T., J. Haas 1997: Triassic sequence stratigraphy of the Balaton Highland, Hungary. - Acta Geologica Hungarica, 40/3, pp. 307-335, Budapest.

Budai, T., A. Vörös 1992: Middle Triassic history of the Balaton Highland: extensional tectonics and basin evolution. - Acta Geologica Hungarica, 35/3, pp. 237-250, Budapest.

Budai, T., G. Császár, G. Csillag, A. Dudko, L. Koloszár, Gy. Majoros 1999: Geology of the Balaton Highland. Explanation to the Geological Map of the Balaton Highland, 1:50 000. - Occasional Papers of the Geological Institute of Hungary, 197, 257 p., Budapest.

Carter, J.L., J.G. Johnson 2006: Spiriferinida. - In: Kaesler, R.L. (Ed.): Treatise on Invertebrate Paleontology. Part H, Brachiopoda (Revised), Volume 5, Rhynchonelliformea (part). Geological Society of America and University of Kansas, Boulder, Colorado and Lawrence, Kansas, pp. 1877-1890.

Diener, C. 1899: Mitteilungen über einige Cephalopodensuiten aus der Trias des südlichen Bakony. (Separatabdruck) - In: Resultate der wissenschaftlichen Erforschung des Balatonsees, 1 (1), Anhang: Palaeontologie der Umgebung des Balatonsees, 3/1, pp. 1-17.

Diener, C. 1900: Neue Beobachtungen über Muschelkalk-Cephalopoden des südl. Bakony. (Separatabdruck) - In: Resultate der wissenschaftlichen Erforschung des Balatonsees, 1 (1), Anhang: Palaeontologie der Umgebung des Balatonsees, 3/2, pp. 21-31. 
Frech, F. 1903: Neue Cephalopoden aus den Buchensteiner, Wengener und Raibler Schichten des südlichen Bakony. (Separatabdr.) - In: Resultate der wissenschaftlichen Erforschung des Balatonsees, 1 (1), Anhang: Palaeontologie der Umgebung des Balatonsees, 3/4, pp. 1-71.

Frech, F. 1904: Neue Zweischaler and Brachiopoden aus der Bakonyer Trias. - In: Resultate der wissenschaftlichen Erforschung des Balatonsees, 1 (1), Anhang: Palaeontologie der Umgebung des Balatonsees, 2/2, pp. 1-137, 140 figs. Budapest

Frech, F. 1907: Die Leitfossilien der Werfener Schichten und Nachträge zur Fauna des Muschelkalkes der Cassianer und Raibler Schichten. - In: Resultate der wissenschaftlichen Erforschung des Balatonsees, 1 (1), Anhang: Palaeontologie der Umgebung des Balatonsees, 2/6, pp. 1-95, 16 pls. Budapest

Haas, J. 1994: Carnian basin evolution in the Transdanubian Central Range, Hungary. - Zentralblatt für Geologie und Paläontologie, Teil I, (1992) 11/12, pp. 1233-1252.

Haas, J., T. Budai 1995: Upper Permian-Triassic facies zones in the Transdanubian Range. - Rivista Italiana Paleontologia e Stratigrafia, 101/3, pp. 249-266, Milano.

Haas, J., T. Budai 1999: Triassic sequence stratigraphy of the Transdanubian Range, Hungary. Geologica Carpathica, 50/6, pp. 459-475, Bratislava.

Haas, J., T. Budai 2004: Dunántúli-középhegységi egység (Transdanubian Range Unit). pp. 25-124. In: Haas, J. (ed.): Magyarország geológiája, Triász (Geology of Hungary, Triassic). - Eötvös Kiadó, Budapest, 384 p.

Haas, J., S. Kovács, Á. Török 1995: Early Alpine shelf evolution in the Hungarian segments of the Tethys margin. - Acta Geologica Hungarica, 38/2, pp. 95-110.

Hornung, T., L. Krystyn, R. Brandner 2007: A Tethys-wide mid-Carnian (Upper Triassic) carbonate productivity crisis: Evidence for the Alpine Reingraben Event from Spiti (Indian Himalaya)? Journal of Asian Earth Sciences, 30, pp. 285-302.

Kittl, E. 1900: Gastropoden aus der Trias des Bakonyerwaldes. In: Resultate der wissenschaftlichen Erforschung des Balatonsees, 1 (1), Anhang: Palaeontologie der Umgebung des Balatonsees, 2/5, pp. 1-229, 10 pls, Wien.

Kittl, E. 1912: Materialen zu einer Monographie der Halobiidae und Monotidae der Trias. - In: Resultate der wissenschaftlichen Erforschung des Balatonsees, 1 (1), Anhang: Palaeontologie der Umgebung des Balatonsees, 2/4, pp. 1-229, 10 pls, Wien.

Kovács, S. 2003: Pelsonian conodonts from the Balaton Highland. - In: Vörös, A. (Ed.): The Pelsonian Substage on the Balaton Highland (Middle Triassic, Hungary). Geologica Hungarica, series Palaeontologica, 55, pp. 159-177.

Lee, D.E., D.I. MacKinnon, TN. Smirnova, P.G. Baker, Jin Yu-gan, Sun Dong-li 2006: Terebratulida. In: Kaesler, R.L. (Ed.): Treatise on Invertebrate Paleontology. Part H, Brachiopoda (Revised), Volume 5, Rhynchonelliformea (part). Geological Society of America and University of Kansas, Boulder, Colorado and Lawrence, Kansas, pp. 1965-2251.

McRoberts, Ch. A. 2001: Triassic bivalves and the initial marine Mesozoic revolution: A role for predators? - Geology, 29/4, pp. 359-362.

Mojsisovics, E. 1882: Die Cephalopoden der mediterranen Triasprovinz. - Abhandlungen der kaiserlich-königlichen geologischen Reichsanstalt, 10, pp. 1-322.

Pálfy, J. 1988: Middle Triassic rhynchonellids from the Balaton Highland (Transdanubian Central Range, Hungary). - Annales Historico-naturale Musei Nationalis Hungarici, 80, pp. 25-46.

Pálfy, J. 2003: The Pelsonian brachiopod fauna of the Balaton Highland. - In: Vörös, A. (ed.): The Pelsonian Substage on the Balaton Highland (Middle Triassic, Hungary). Geologica Hungarica, series Palaeontologica, 55, pp. 139-158.

Piros, O. 2003: The Pelsonian Dasycladales of the Balaton Highland. - In: Vörös, A. (Ed.): The Pelsonian Substage on the Balaton Highland (Middle Triassic, Hungary). Geologica Hungarica, series Palaeontologica, 55, pp. 53-69.

Preto, N., E. Kustatscher, P.B. Wignall 2010: Triassic climates - state of the art and perspectives. Palaeogeography, Palaeoclimatology, Palaeoecology, 290, pp. 1-10. 
Rigo, M., N. Preto, G. Roghi, F. Tateo, P. Mietto 2007: A rise in the carbonate compensation depth of western Tethys in the Carnian (Late Triassic): Deep-water evidence for the Carnian Pluvial Event. - Palaeogeography, Palaeoclimatology, Palaeoecology, 246, pp. 188-205.

Savage, N.M., M.O. Manceñido, E.F. Owen, S.J. Carlson, R.E. Grant, A.S. Dagys, Sun Dong-li 2002: Rhynchonellida. - In: Kaesler, R.L. (Ed.): Treatise on Invertebrate Paleontology. Part H, Brachiopoda (Revised), Volume 4, Rhynchonelliformea (part): Geological Society of America and University of Kansas, Boulder, Colorado and Lawrence, Kansas, pp. 1027-1376.

Schatz, W. 2005: Palaeoecology of the Triassic black shale bivalve Daonella - new insights into an old controversy. - Palaeogeography, Palaeoclimatology, Palaeoecology, 216/3-4, pp. 189-201.

Schubert, J.K., D.J. Bottjer 1995: Aftermath of the Permian-Triassic mass extinction event: paleoecology of Lower Triassic carbonates in the western USA. - Palaeogeography, Palaeoclimatology, Palaeoecology, 116, pp. 1-39.

Szabó, I. 1972: Triász [Triassic]. - In: Deák, M. (Ed.): Magyarázó Magyarország 200.000-es földtani térképsorozatához [Explanatory notes to the geological map series of Hungary, 1:200.000]. L-33XXII, Veszprém. MÁFI, Budapest, pp. 34-72.

Szente, I., A. Vörös 2003: The Pelsonian Bivalvia fauna of the Balaton Highland. - In: Vörös, A. (Ed.) The Pelsonian Substage on the Balaton Highland (Middle Triassic, Hungary). Geologica Hungarica, series Palaeontologica, 55, pp. 123-137.

Tozer, E.T. 1984: The Trias and its ammonoids: the evolution of a time scale. - Geological Survey of Canada, Miscellaneous Report, 35, pp. 1-171.

Visscher, H., M. Van Houte, W.A. Brugman, R.J. Poort 1994: Rejection of a Carnian (Late Triassic) "pluvial event" in Europe. - Review of Palaeobotany and Palynology, 83/1-3, pp. 217-226.

Vörös ,A. 1987: Preliminary results from the Aszófő section (Middle Triassic, Balaton area, Hungary): a proposal for a new Anisian ammonoid subzonal scheme. - Fragmenta Mineralogica et Palaeontologica, 13, pp. 53-64.

Vörös, A. 1993: Redefinition of the Reitzi Zone at its type region (Balaton area, Hungary) as the basal zone of the Ladinian. - Acta Geol. Hung., 36/1, pp. 15-38.

Vörös, A. 1996: Environmental distribution and bathymetric significance of Middle Triassic ammonoid faunas from the Balaton Highland, Hungary. - Fragmenta Mineralogica et Palaeontologica, 18, pp. 5-17.

Vörös, A. 1998: A Balaton-felvidék triász ammonoideái és biosztratigráfiája [Triassic ammonoids and biostratigraphy of the Balaton Highland]. - Studia Naturalia, 12, pp. 1-105, Budapest.

Vörös, A. (Ed.) 2003a: The Pelsonian Substage on the Balaton Highland (Middle Triassic, Hungary) Geologica Hungarica, series Palaeontologica, 55, pp. 1-195.

Vörös, A. 2003b: The Pelsonian ammonoid fauna of the Balaton Highland. - In: Vörös, A. (Ed.): The Pelsonian Substage on the Balaton Highland (Middle Triassic, Hungary). Geologica Hungarica, series Palaeontologica, 55, pp. 71-121.

Vörös, A., T. Budai, Gy. Lelkes, M. Monostori, J. Pálfy 1997: A Balaton-felvidéki középsô-triász medencefejlődés rekonstrukciója üledékföldtani és paleoökológiai vizsgálatok alapján (Middle Triassic basin evolution of the Balaton Highland (Hungary) based on sedimentological and paleoecological studies). - Földtani Közlöny, 127/1-2, pp. 145-177.

Vörös, A., T. Budai, J. Haas, S. Kovács, H. Kozur, J. Pálfy 2003: GSSP (Global Boundary Stratotype Section and Point) proposal for the base of Ladinian (Triassic). A proposal for the GSSP at the base of the Reitzi Zone (sensu stricto) at Bed 105 in the Felsöörs section, Balaton Higland, Hungary. - Albertiana, 28, pp. 35-47.

Vörös, A., I. Szabó, S. Kovács, L. Dosztály, T. Budai 1996: The Felsöörs section: A possible stratotype for the base of the Ladinian stage. - Albertiana, 17, pp. 25-40.

Vörös, A., J. Pálfy 1989: The Anisian/Ladinian boundary in the Vászoly section (Balaton Highland, Hungary). - Fragmenta Mineralogica et Palaeontologica, 14, pp. 17-27.

Vörös, A., J. Pálfy 2002: New data to the stratigraphy of the Pelsonian Substage at Köveskál (Middle Triassic, Balaton Highland, Hungary). - Fragmenta Palaeontologica Hungarica, 20, pp. 53-60. 